\title{
Downscaling a global climate model to simulate climate change over the US and the implication on regional and urban air quality
}

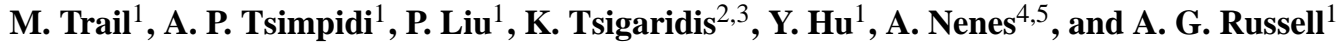 \\ ${ }^{1}$ School of Civil \& Environmental Engineering, Georgia Institute of Technology, Atlanta, GA 30332, USA \\ ${ }^{2}$ Center for Climate Systems Research, Columbia University, New York, NY 10025, USA \\ ${ }^{3}$ NASA Goddard Institute for Space Studies, New York, NY 10025, USA \\ ${ }^{4}$ School of Earth \& Atmospheric Sciences, Georgia Institute of Technology, Atlanta, GA 30332, USA \\ ${ }^{5}$ School of Chemical and Biomolecular Engineering, Georgia Inst. Technology, Atlanta, GA 30332, USA
}

Correspondence to: M. Trail (mcus2rail@gmail.com)

Received: 25 February 2013 - Published in Geosci. Model Dev. Discuss.: 15 April 2013

Revised: 15 July 2013 - Accepted: 30 July 2013 - Published: 9 September 2013

\begin{abstract}
Climate change can exacerbate future regional air pollution events by making conditions more favorable to form high levels of ozone. In this study, we use spectral nudging with the Weather Research and Forecasting (WRF) model to downscale NASA earth system GISS modelE2 results during the years 2006 to 2010 and 2048 to 2052 over the contiguous United States in order to compare the resulting meteorological fields from the air quality perspective during the four seasons of five-year historic and future climatological periods. GISS results are used as initial and boundary conditions by the WRF regional climate model (RCM) to produce hourly meteorological fields. The downscaling technique and choice of physics parameterizations used are evaluated by comparing them with in situ observations. This study investigates changes of similar regional climate conditions down to a $12 \mathrm{~km}$ by $12 \mathrm{~km}$ resolution, as well as the effect of evolving climate conditions on the air quality at major US cities. The high-resolution simulations produce somewhat different results than the coarse-resolution simulations in some regions. Also, through the analysis of the meteorological variables that most strongly influence air quality, we find consistent changes in regional climate that would enhance ozone levels in four regions of the US during fall (western US, Texas, northeastern, and southeastern US), one region during summer (Texas), and one region where changes potentially would lead to better air quality during spring (Northeast). Changes in regional climate that would enhance ozone levels are increased temperatures and stagnation along with decreased precipitation and ventilation. We
\end{abstract}

also find that daily peak temperatures tend to increase in most major cities in the US, which would increase the risk of health problems associated with heat stress. Future work will address a more comprehensive assessment of emissions and chemistry involved in the formation and removal of air pollutants.

\section{Introduction}

Changes in climate, emissions, population, technologies, and land use can impact air quality in a variety of ways. Studies suggest that climate change can exacerbate future regional air pollution events (e.g., Liao et al., 2006; Mickley et al., 2004; Stevenson et al., 2006; Weaver et al., 2009) by making conditions more favorable to form high levels of ozone, e.g., by increasing temperature and biogenic emissions and decreasing ventilation. Increased temperatures affect air quality by affecting reaction rates and gas solubility in water droplets (EPA, 1989). Pollutant dispersion and removal are affected by large-scale circulation patterns and precipitation, while cloud cover frequency and duration impacts photolytic activity, which in turn affects reaction rate coefficients and conversion of gases to aerosols. Stagnation event frequency and duration affects the mixing of polluted air with air above the boundary layer. To simulate regional air quality dynamics, results from global models are downscaled using dynamical downscaling. The starting point of dynamical downscaling is typically a set of coarse-resolution 
large-scale meteorological fields (either from a general circulation model, GCM, or from global reanalysis data) which are used to provide the initial, and lateral and surface boundary conditions to a regional climate model (RCM). Typically the RCM simulation does not feed back into the GCM, but adds regional detail in response to finer-scale forcing (e.g., topography, land use/land cover) as it interacts with the larger-scale atmospheric circulation (Giorgi, 2006). In this study, we address the benefits of downscaling using an RCM when analyzing the implications of climate change on air quality and health, especially in urban areas.

Recently, climate modeling efforts have shifted their focus from analyzing mean values of climate variables (e.g., temperature and precipitation) to extreme values, variability, and shifts in the frequency of climate patterns that are more relevant for air quality. Jacob and Winner (2009) compiled results from a number of studies on climate change and air pollution, and summarized that increases in regional stagnation consistently increase ozone and particulate matter (PM) concentrations. They show that positive temperature perturbations consistently increase ozone while they can sometimes decrease PM concentrations and that positive perturbations in mixing depth, wind speed, cloud cover, and precipitation all decrease ozone and PM concentrations to varying degrees. Mickley et al. (2004) applied the Goddard Institute for Space Studies (GISS) GCM 2' (Rind and Lerner, 1996; Rind et al., 1999) with implemented carbon monoxide (CO) and black carbon (BC) tracers to simulate the impact of climate change on air quality in the US. They found that increased severity of future pollutant episodes in the Northeast and Midwest during the summer was due to a decrease in frequency of surface cyclone tracking in southern Canada.

Dawson et al. (2008) developed a global-regional climateair pollution modeling system (GRE-CAPS) by coupling GISS II GCM, MM5 regional meteorological model, and the PMCAMx regional CTM. This system was intended to enable studies of the effects of changes in climate, intercontinental transport, and emissions on regional and urban air quality. Leung and Gustafson (2005) applied a similar approach to assess the potential effects of climate change in the United States. They developed meteorological fields by downscaling the NASA GISS GCM simulations using an MM5-based RCM (Grell et al., 1994). Their analyses were based on changes in surface air temperature and downward solar radiation, precipitation frequency, stagnation events, and ventilation. They defined a time to be stagnant when for four consecutive days the following criteria are met: (a) the $10 \mathrm{~m}$ wind speed is less than $4 \mathrm{~m} \mathrm{~s}^{-1}$, (b) the $500 \mathrm{mb}$ wind speed is less than $13 \mathrm{~m} \mathrm{~s}^{-1}$ at 07:00 LST, and (c) the total rainfall is less than $0.001 \mathrm{~cm}$ for the 4-day period (Korshover and Angell, 1982). They also compared the daily average number of unvented hours, which are hours when the product of the mean wind speed within the boundary layer and the boundary layer height is less than $6000 \mathrm{~m}^{2} \mathrm{~s}^{-1}$ (Pielke et al., 1991). In Tagaris et al. (2007), meteorological inputs to the Community Multi-scale Air Quality (CMAQ) chemistry/transport model (CTM) were developed using the meteorological fields of Leung and Gustafson (Leung and Gustafson, 2005) to investigate the potential impacts of global climate change and emissions on regional air quality using CMAQ (Byun and Schere, 2006). Similarly, Nolte et al. (2008) investigated the impact of climate change on future air quality in the United States by dynamically downscaling outputs from the GISS GCM with the MM5 RCM and predicted an increase in $\mathrm{O}_{3}$ over Texas and large portions of the Southeast using CMAQ model.

These studies have illustrated the value of using the regional downscaling approach in order to better understand the impact of climate change on regional air quality. With the strong dependence on localized flow patterns, air quality models benefit from the higher-resolution wind, temperature, precipitation, and boundary layer structures produced by a RCM (Leung and Gustafson, 2005). Weaver et al. (2009) stresses that the science of coupling global climate and regional air quality models is still at a young state and that there are particular questions as to which climate metrics and statistics are most relevant to air quality and how sensitive simulation results are to downscaling methodologies.

In our previous recent work (Liu et al., 2012) we examined the performance of two nudging techniques, grid and spectral nudging, by downscaling NCEP/NCAR data using the Weather Research and Forecasting (WRF) model and identified benefits of spectral nudging at producing small-scale features while preserving the large-scale forcings. Following these findings, in this study, we use spectral nudging to downscale the NASA earth system GISS modelE2 results during the years 2006 to 2010 and 2048 to 2052 over the contiguous United States (CONUS) in order to compare the resulting meteorological fields from the air quality perspective during the four seasons of five-year historic and future climatological periods. GISS results are used as initial and boundary conditions by the WRF RCM to produce hourly meteorological fields. The downscaling technique and choice of physics parameterizations used are evaluated by comparing them with in situ observations. This study investigates changes of similar regional climate conditions down to a $12 \mathrm{~km}$ by $12 \mathrm{~km}$ resolution, as well as the implications of evolving climate conditions on the air quality at major US cities.

\section{Approach}

In this study a regional climate model is used to downscale a global climate model to develop meteorological fields for the present and future. Each component of the modeling system is described below along with the downscaling and evaluation methods used. 


\subsection{Model descriptions}

\subsubsection{Global model}

Lateral boundary and initial conditions for the regional forecast modeling are taken from the GISS ModelE2. The model has a horizontal resolution of $2^{\circ} \times 2.5^{\circ}$ latitude by longitude. The vertical discretization has 40 layers and follows a sigma coordinate up to $150 \mathrm{hPa}$, with constant pressure layers between 150 and $0.1 \mathrm{hPa}$. The surface is split into four types: open water (including lakes, rivers and oceans), ice-covered water (including lake ice and sea ice), ground (including bare soil and vegetated regions) and glaciers.

Simulations are carried out for the calendar years 20062010 and 2048-2052, driven by future atmospheric conditions over the 21 st century and follow the scenario development process for IPCC AR5. The specific scenario used for this study is the "Representative Concentration Pathway" (RCP) 4.5 (Lamarque et al., 2011; Moss et al., 2010), which is a scenario of decadal global emissions of greenhouse gases, short-lived species, and land use/land cover which produces an anthropogenic radiative forcing at $4.5 \mathrm{~W} \mathrm{~m}^{-2}$ (approximately $650 \mathrm{ppm} \mathrm{CO}$-equivalent) in the year 2100 . The detailed characteristics of this scenario are enumerated in Moss et al. (2010). The atmosphere/terrestrial biosphereonly version of the GISS modelE2 was driven by sea-ice and sea-surface temperature conditions calculated by the coupled earth system model version that is submitted to the CMIP5 archive. The model spinup time was $3 \mathrm{yr}$, starting either from 2003 or 2045, which is sufficient for the dynamic equilibration of the model's climate and chemically active tracers. SST and sea-ice boundary conditions vary both seasonally and interannually, GHG concentrations change annually, and emissions change annually by linearly interpolating the decadal CMIP5 emission datasets. Six-hourly instantaneous outputs of physical parameters were produced for regional downscaling by WRF (Sect. 2.2). Six-hourly instantaneous outputs of gaseous and aerosol tracer concentrations were also produced, but were not used for downscaling.

\subsubsection{Regional model}

The regional climate model used is the non-hydrostatic Weather Research and Forecasting (WRF) model (Skamarock and Klemp, 2008) version 3.4. The simulation domain covers the CONUS and portions of southern Canada and northern Mexico and is centered at $40^{\circ} \mathrm{N}$ and $97^{\circ} \mathrm{W}$ with dimensions of $164 \times 138$ horizontal grids cells with a grid spacing of $36 \mathrm{~km}$. It contains 35 vertical levels, with the top pressure of $50 \mathrm{hPa}$. The configuration of physics schemes is as follows: the longwave Rapid Radiative Transfer Model (RRTM) (Mlawer et al., 1997) and Dudhia scheme (Dudhia, 1989) are used for longwave and shortwave radiation, respectively; the Yonsei University (YSU) (Hong et al., 2006) scheme is used for the planetary boundary layer; the Noah scheme (Ek et al., 2003) is used for land surface model (LSM); a revised version of the Kain-Fritsch scheme (Kain and Fritsch, 1993) is used to represent the effects of both deep and shallow cumulus clouds; Lin et al. (1983) is chosen for cloud microphysics.

\subsection{Dynamical downscale of global results}

The GISS ModelE2 fields include temperature, relative humidity, horizontal wind velocities, soil temperature and moisture at different soil depths, sea surface temperature, surface pressure, ice fraction and snow water equivalent. The WRF Preprocessing System (WPS), which reads in these global data and interpolates them to the WRF grid points, does not process GISS data directly. Therefore, an interface program was developed to link the GISS output with WPS. Three-dimensional variables, such as wind and temperature, are interpolated to 21 fixed pressure levels; the lowest level of these 3-D variables and surface level properties were vertically interpolated to produce $2 \mathrm{~m}$ temperature, $2 \mathrm{~m}$ humidity, and $10 \mathrm{~m}$ wind fields. The soil-related variables were also interpolated to the depths defined from the LSM.

Global model results are used as initial and boundary conditions for the regional climate simulations. Spectral nudging with a wave number of 3 in both zonal and meridional directions is used; i.e., all waves with wave numbers greater than 3 are filtered (Liu et al., 2012); no nudging is conducted for shorter waves to provide similarity with the large-scale GCM simulation but allow small-scale features to freely develop (Liu et al., 2012). Spectral nudging is applied to temperature, horizontal winds, and geopotential heights. Only horizontal winds are nudged at all vertical levels, while no nudging is conducted for other variables within the planetary boundary layer (PBL). The nudging coefficient for all variables was set to $3 \times 10^{-4} \mathrm{~s}^{-1}$ (Stauffer and Seaman, 1990). During the simulation, nudging is conducted every $6 \mathrm{~h}$, consistent with the frequency of the GISS data.

\section{Model application and evaluation}

WRF is applied here using a nested grid approach. The modeling domain uses a Lambert conformal projection centered at $40^{\circ} \mathrm{N}, 97^{\circ} \mathrm{W}$ with true latitudes of $33^{\circ} \mathrm{N}$ and $45^{\circ} \mathrm{N}$. The outer domain uses a $36 \mathrm{~km}$ horizontal grid spacing that covers the entire contiguous US as well as portions of Canada and Mexico $(5940 \mathrm{~km} \times 5004 \mathrm{~km})$. Two innermost domains cover $984 \mathrm{~km} \times 1020 \mathrm{~km}$ and $948 \mathrm{~km} \times 948 \mathrm{~km}$ regions with $12 \mathrm{~km}$ horizontal grid spacing and focusing on the northeastern and southeastern US, respectively (Fig. 1). The periods modeled are 2006 through 2010 (historic) and 2048 to 2052 (future). The simulated coarse-grid hourly meteorology is used as initial and boundary conditions for the finer grids.

Observations are used to evaluate the ability of GISS-WRF to reproduce the long-term yearly climatic means, and the 


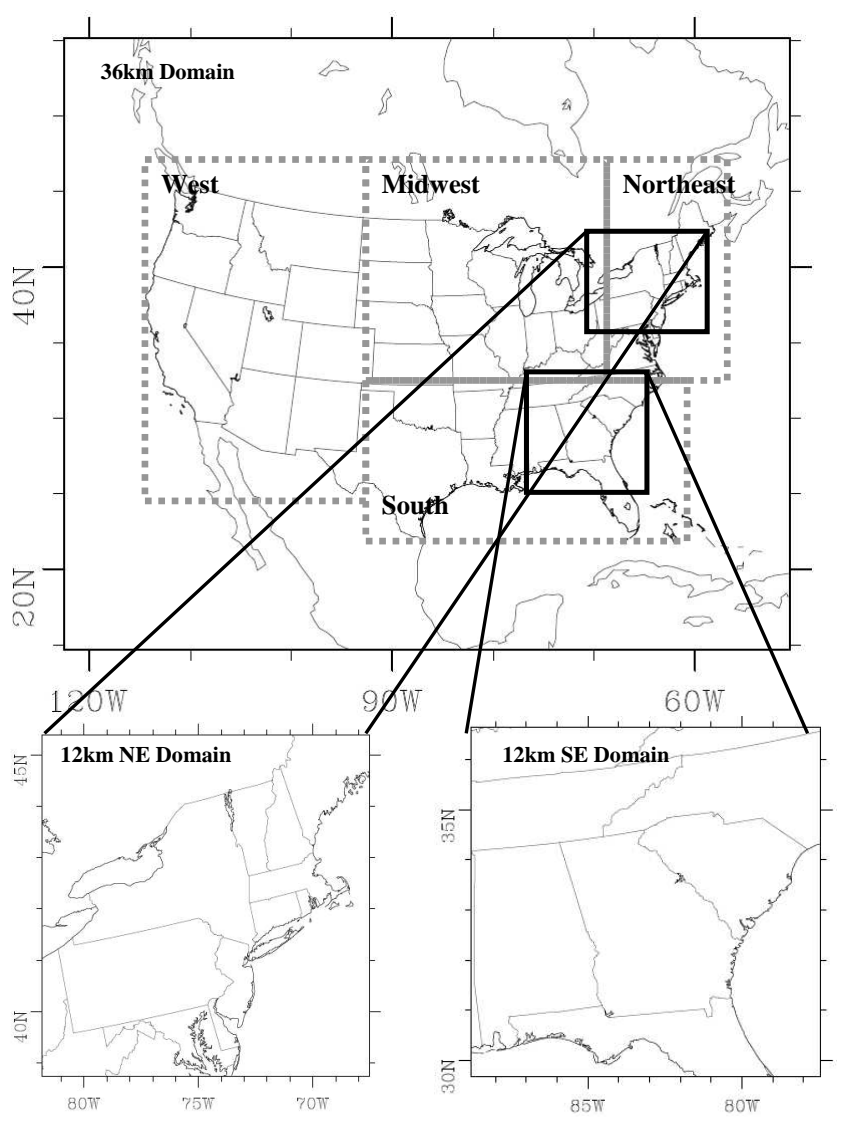

Fig. 1. Modeling domains with horizontal grid spacing resolutions of $36 \mathrm{~km}$ and $12 \mathrm{~km}$ Northeast (NE) and Southeast (SE). The dashed boxes indicate the four regions where model evaluation was conducted.

meteorological fields that strongly impact air quality. The model performance is evaluated by using statistical measures. This is a common analysis that is proposed by Emery and Tai (Emery, 2001) and has been adopted by the meteorological modeling community. Statistics such as mean bias (MB), mean absolute gross error (MAGE) and root mean square error (RMSE) are calculated:

$$
\begin{aligned}
\text { MAGE } & =\frac{1}{N} \sum_{i=1}^{N}\left|P_{i}-O_{i}\right| \\
\mathrm{MB} & =\frac{1}{N} \sum_{i=1}^{N}\left(P_{i}-O_{i}\right) \\
\mathrm{RMSE} & =\sqrt{\frac{1}{N} \sum_{i=1}^{N}\left(P_{i}-O_{i}\right)^{2},}
\end{aligned}
$$

where $P_{i}$ is the predicted value of the tested parameter (i.e., temperature), $O_{i}$ is the corresponding observed value, and $N$ is the total number of the predictions used for the comparison. MAGE gives an estimation of the overall discrepancy between predictions and observations, while MB is sensitive to systematic errors. RMSE incorporates both the variance of the prediction and its bias. Additional details for the above evaluation metrics can be found in Yu et al. (2006). The observations used for the statistical analysis are TDL (Techniques Development Laboratory) data from the Research Data Archive (RDA) (http://dss.ucar.edu in dataset number ds472.0), which is maintained by the Computational and Information Systems Laboratory (CISL) at the National Center for Atmospheric Research (NCAR). These are hourly surface observations for wind speed, wind direction, and temperature during the four seasons over a five-year period (2006-2010). In the statistical analysis, the contiguous US domain has been divided in 4 sub-regions, the West (W), the Midwest (MW), the South (S) and the Northeast (NE) USA (Fig. 1).

\section{Results}

Table 1 summarizes the comparison of the GISS-WRF modeling system simulations for wind speed and direction against TDL hourly surface observations during the four seasons of a five-year period (2006-2010) over four regions of the contiguous USA: the West, the Midwest, the South, and the Northeast. Overall the model predictions agree well with observations with the MB over the total domain ranging between $-0.1 \mathrm{~m} \mathrm{~s}^{-1}$ (during summer) $0.2 \mathrm{~m} \mathrm{~s}^{-1}$ (during spring). Model performance is better during summer with RMSE as a low as $2.2 \mathrm{~m} \mathrm{~s}^{-1}$ over the South and worst during winter with RMSE over the West up to $3.9 \mathrm{~m} \mathrm{~s}^{-1}$. Wind speed is better predicted over the South (with MAGE ranging from $1.7 \mathrm{~m} \mathrm{~s}^{-1}$ to $2.2 \mathrm{~m} \mathrm{~s}^{-1}$ ), while wind direction is better predicted over the Northeast (with MAGE ranging from $72 \mathrm{deg}$. to $78 \mathrm{deg}$.). Table 2 summarizes the comparison of the GISS-WRF modeling system predictions for temperature against observational data during the four seasons over the contiguous USA. Compared to observations, the model tends to under-predict temperature during winter (MB up to $-7.5 \mathrm{~K}$ ), spring (MB up to $-2.7 \mathrm{~K}$ ), and summer (MB up to $-1.9 \mathrm{~K}$ over the West) but over-predict temperature during fall (MB up to $2.9 \mathrm{~K}$ ). The low temperature bias over the western US corresponds to low biases in the GISS fields. Model performance is better over the southern US, especially during summer $(\mathrm{RMSE}=3.5 \mathrm{~K})$.

\subsection{Temperature}

The $5 \mathrm{yr}$ mean of the modeled $2 \mathrm{~m}$ air temperature across the simulation domain for the future is $1 \mathrm{~K}$ warmer than that of the historical simulation (284 and $285 \mathrm{~K}$, respectively) (Fig. 2). Consistent with other studies (Leung and Gustafson, 2005; Liao et al., 2007; Nolte et al., 2008; Tagaris et al., 2007; Woo et al., 2008) most of the warming, between 3 and $4 \mathrm{~K}$, occurs over the western states (California, Nevada, Arizona, Texas, and Utah) and over western Canada (Fig. 2a), and the results of a $t$ test suggest that the warming in this 


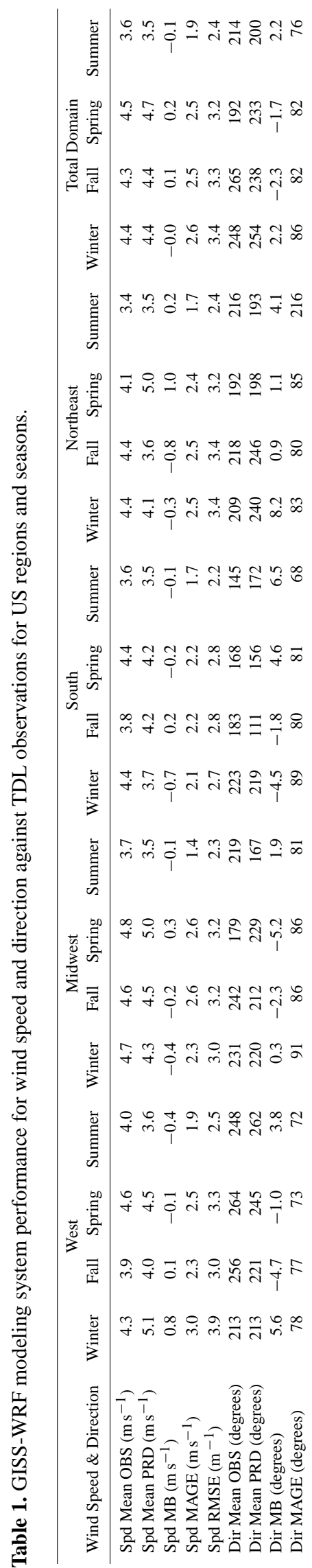




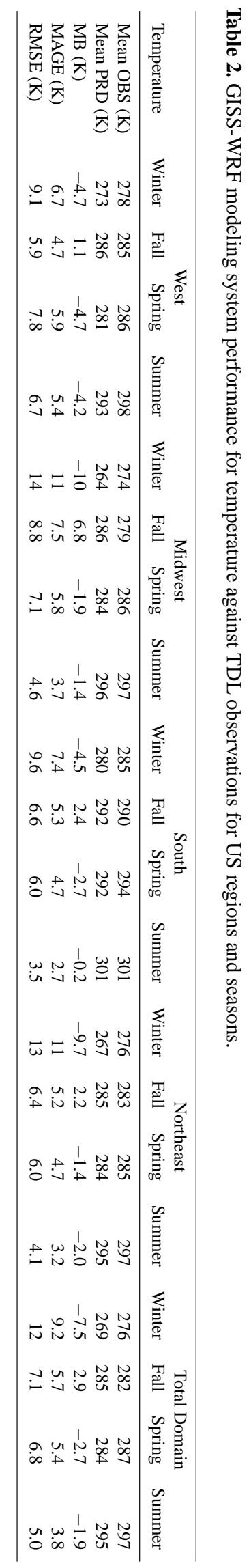



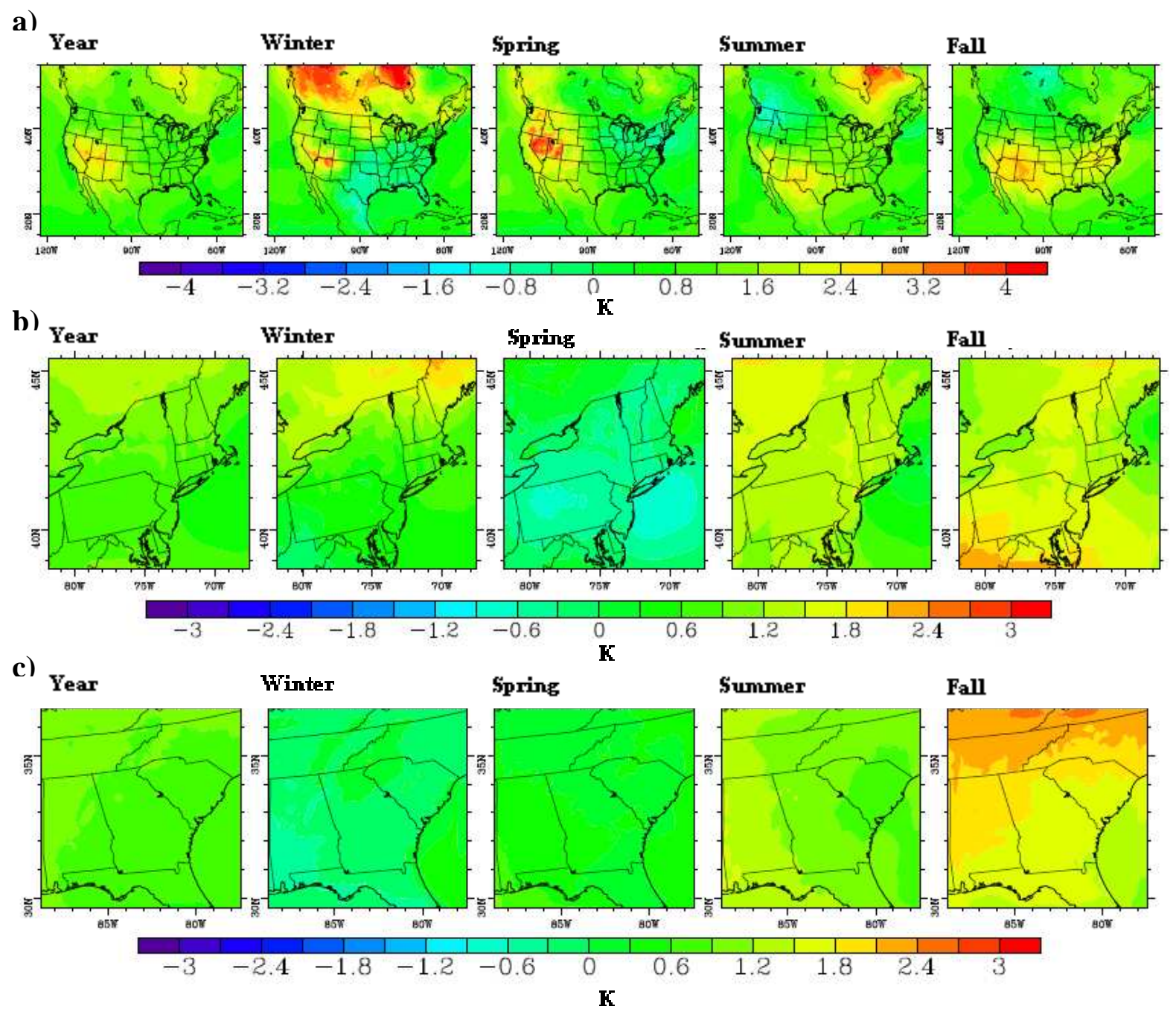

Fig. 2. Predicted average yearly and seasonal $2 \mathrm{~m}$ atmospheric temperature change (future minus historic) for (a) the $36 \mathrm{~km} \times 36 \mathrm{~km}$ resolution modeling domain, (b) the $12 \mathrm{~km} \times 12 \mathrm{~km}$ resolution sub-domain over the Northeast and (c) the $12 \mathrm{~km} \times 12 \mathrm{~km}$ resolution sub-domain over the Southeast.

Table 3. The average present (2006-2009) and future (2048-2052) upper 95th percentile in daily maximum temperatures for Atlanta, Los Angeles, Philadelphia, Phoenix and Seattle.

\begin{tabular}{lrr}
\hline $\begin{array}{l}\text { 95th } \\
\text { Percentile }\end{array}$ & $\begin{array}{r}\text { 2006-2010 } \\
\text { Average }\end{array}$ & $\begin{array}{r}\text { 2048-2052 } \\
\text { Average }\end{array}$ \\
\hline Atlanta 36 km & 302 & 304 \\
Atlanta $12 \mathrm{~km}$ & 303 & 305 \\
Los Angeles & 302 & 305 \\
Philadelphia 36 km & 301 & 304 \\
Philadelphia 12 km & 303 & 305 \\
Phoenix & 306 & 309 \\
Seattle & 299 & 298 \\
\hline
\end{tabular}

region is statistically significant ( $p$ value $<0.05$ in this region). Significant warming mainly occurs over these regions during the winter and spring months, where average surface temperature change reaches 4 degrees in western states, especially in and around Nevada (the $p$ value is less than 0.05 for these temperature increases). Since temperatures are low during the winter and spring, warming during these seasons may not lead to increased concentrations of secondary pollutants such as $\mathrm{O}_{3}$ and secondary PM, but warming could lead to decreased emissions of PM from heating processes such as wood burning (e.g., from wood stoves). The GCM simulations predict a similar warming pattern during the winter and spring, but only up to 3 degrees K (Fig. S1). During the summer months, Texas and northeastern Canada experience a warming of 2 and 4 degrees, respectively, although the GCM predicts up to one degree more warming over western Texas 


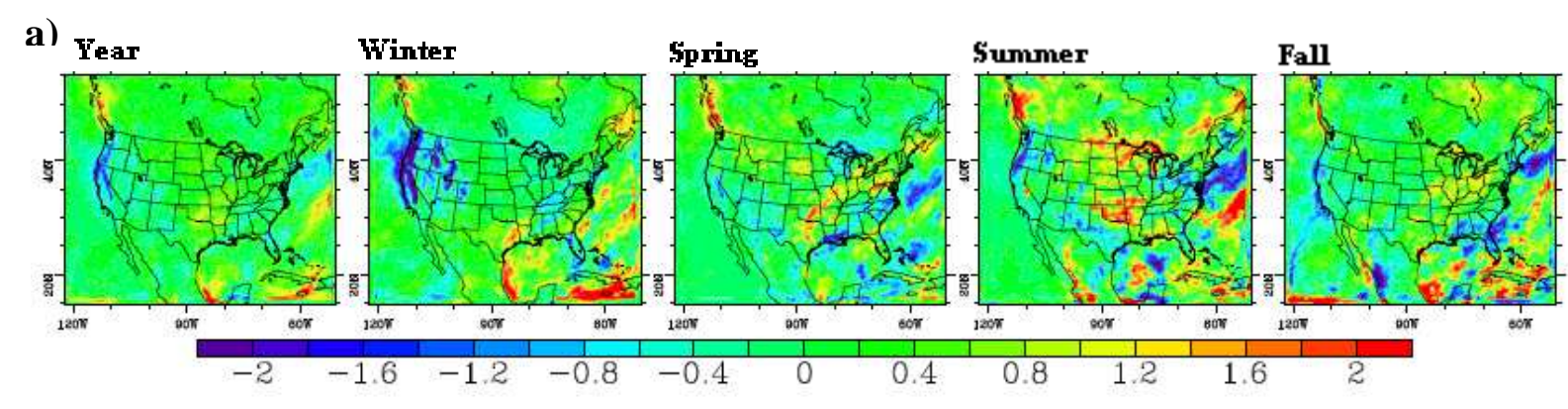

b) Year

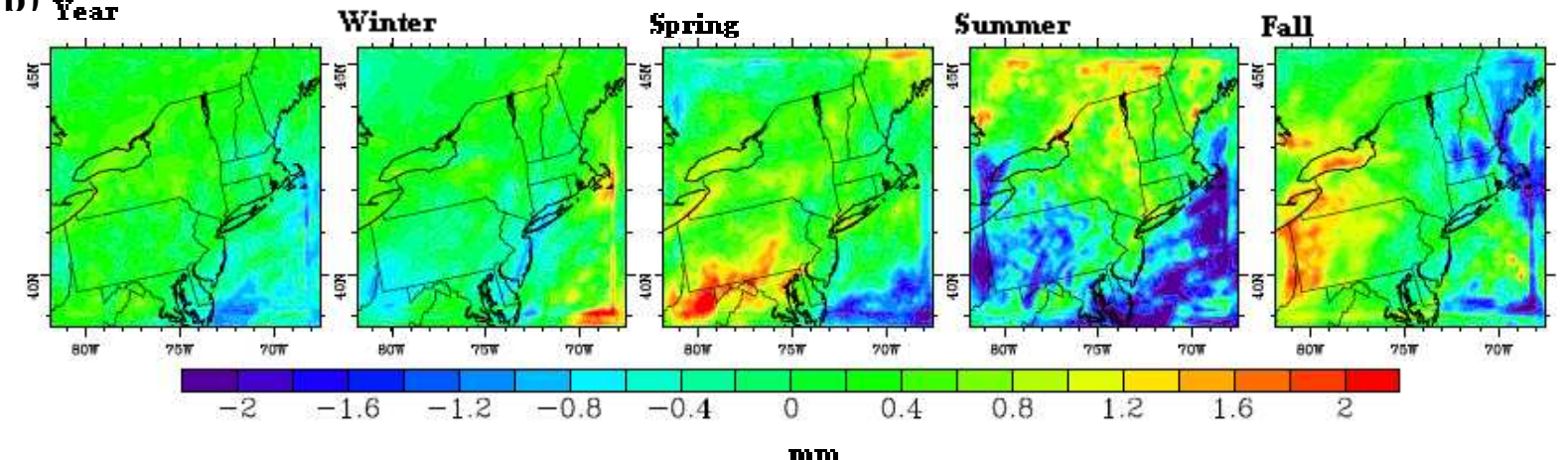

c) Year

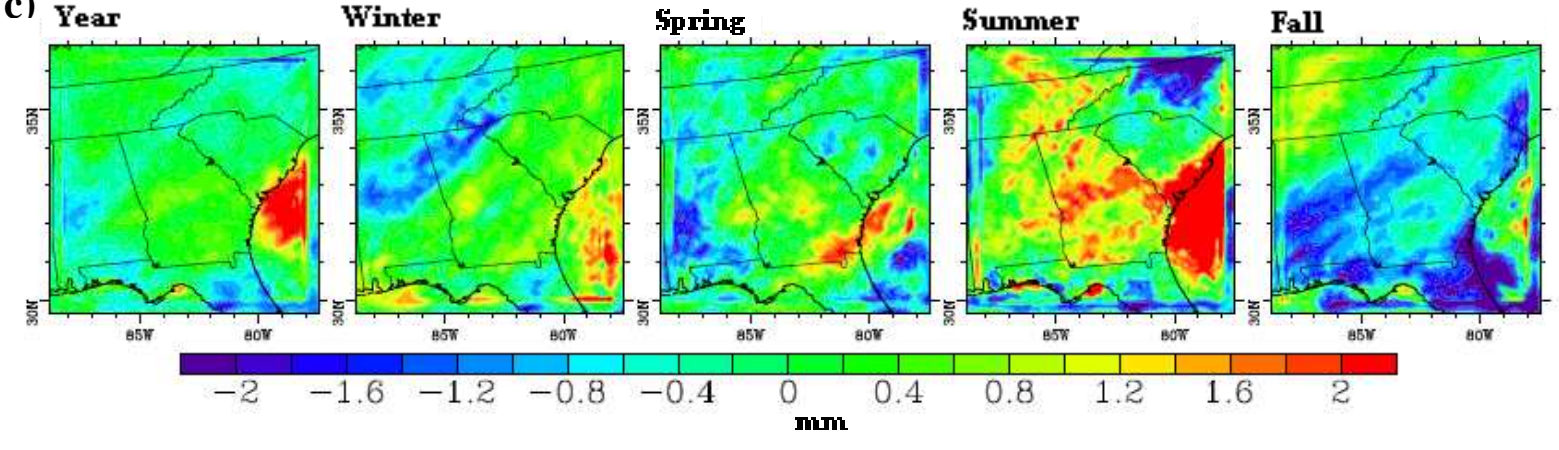

Fig. 3. (a) Predicted average yearly and seasonal precipitation $\left(\mathrm{mm} \mathrm{day}^{-1}\right.$ ) change (future minus historic) for (a) the $36 \mathrm{~km} \times 36 \mathrm{~km}$ resolution modeling domain, (b) the $12 \mathrm{~km} \times 12 \mathrm{~km}$ resolution sub-domain over the Northeast and (c) the $12 \mathrm{~km} \times 12 \mathrm{~km}$ resolution sub-domain over the Southeast.

and the $p$ value associated with the downscaled temperature changes over western Texas is between 0.05 and 0.10 . An average warming of 3 degrees occurs over the Midwest ( $p$ value $<0.05$ ) and a warming of around 2 degrees also occurs over most of Texas and the eastern US (the $p$ value is between 0.05 and 0.15 , which is not significant) during the fall. The eastern US states, on the other hand, are cooler during the winter and spring months, with the southeastern states and Texas cooling up to just less than 2 degrees; however the cooling here is not statistically significant ( $p$ value greater than 0.05).

The smaller, more highly resolved $12 \mathrm{~km}$ domain over the Northeast simulates similar magnitudes of temperature change to the $36 \mathrm{~km}$ domain. The root mean square difference of the future temperature change between the $36 \mathrm{~km}$ and $12 \mathrm{~km}$ domains is very small (less than $0.004 \mathrm{~K}$ ), indicating the similarity between the two simulations. The standard deviations of the simulated temperature changes in the Northeast for the $12 \mathrm{~km}$ (standard deviation of $0.25 \mathrm{~K}$ ) and $36 \mathrm{~km}(0.24 \mathrm{~K})$ domains show that the fine-resolution simulation introduces slightly more variability than the coarseresolution domain, especially during the winter $(0.49 \mathrm{~K}$ for the $36 \mathrm{~km}$ and $0.52 \mathrm{~K}$ for $12 \mathrm{~km})$ and spring $(0.27 \mathrm{~K}$ for $36 \mathrm{~km}$ and $0.29 \mathrm{~K}$ for $12 \mathrm{~km}$ ). The Northeast sees cooling of less than 1 degree during the spring and warming of up to 2 degrees during the summer (Fig. 2b). During fall, large warming between 2 and 3 degrees is simulated over much of New York State. Over the southeastern $12 \mathrm{~km}$ domain, similar warming occurs to the $36 \mathrm{~km}$ domain, ranging between 1 and 3 degrees during the summer and fall, with the greatest warming occurring during the fall over North Carolina and Tennessee (Fig. 2c). 


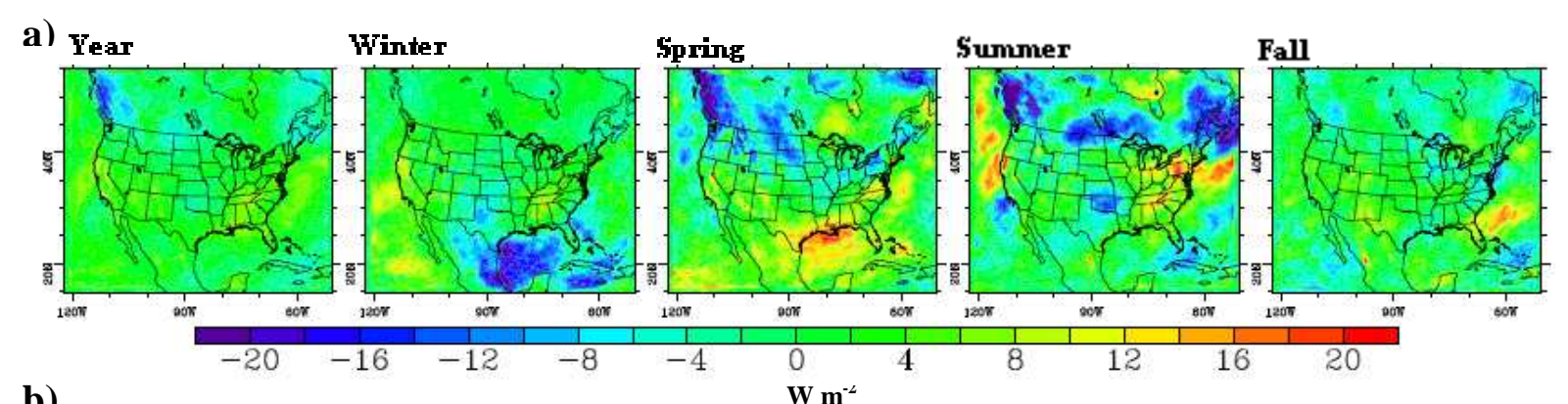

b)

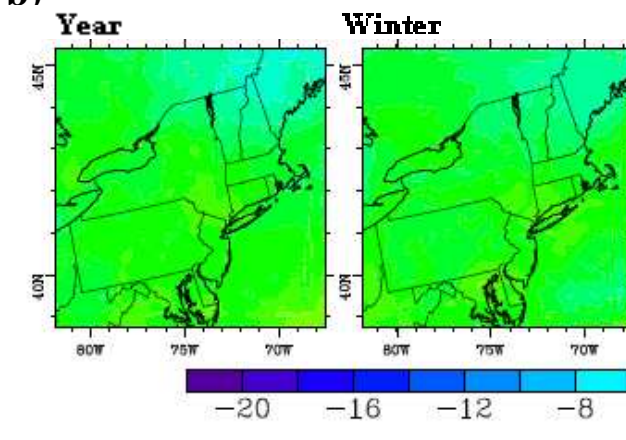

spring

$\mathbf{W} \mathbf{m}^{-4}$

c)

Year

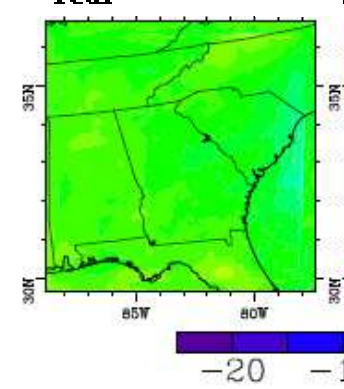

Winter

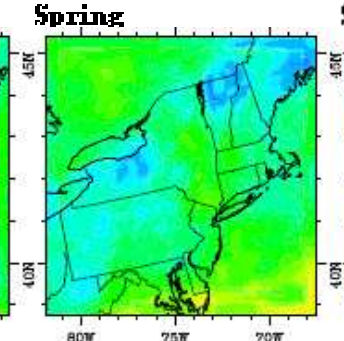

Summer

Fall
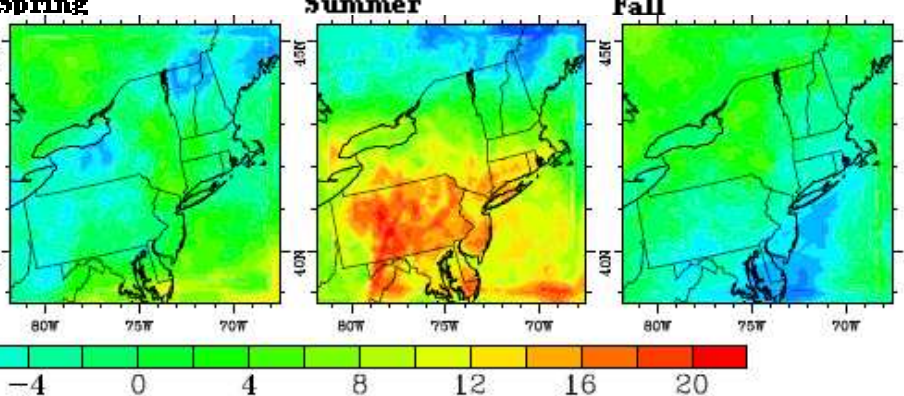

$\mathbf{W} \mathbf{m}^{-2}$

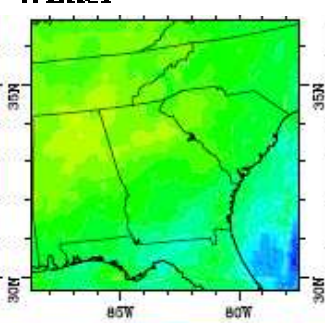

Spring

summer

Fall
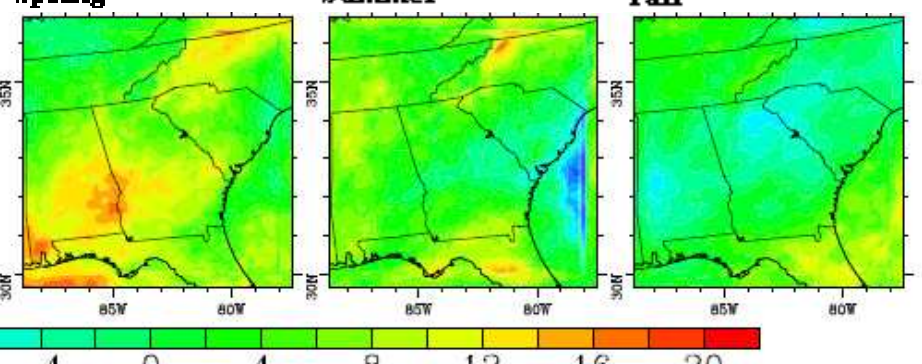

$\mathbf{W} \mathbf{m}^{-2}$

Fig. 4. Predicted average yearly and seasonal downward shortwave radiative flux at the surface $\left(\mathrm{W} \mathrm{m}^{-2}\right.$ ) change (future minus historic) for (a) the $36 \mathrm{~km} \times 36 \mathrm{~km}$ resolution modeling domain, (b) the $12 \mathrm{~km} \times 12 \mathrm{~km}$ resolution sub-domain over the Northeast and (c) the $12 \mathrm{~km} \times 12 \mathrm{~km}$ resolution sub-domain over the Southeast.

\subsection{Insolation and precipitation}

A change in downward solar radiation at the surface, or insolation, is an indicator of changes in cloudiness. For this reason, spatial distributions of the change in insolation at the surface are similar in structure to average daily precipitation, but not identical. Spatial distributions of surface temperature and insolation changes have similar structures in some cases. Weaver et al. (2009) explain that these meteorological conditions can have either competing or reinforcing effects on air quality. When temperature and insolation change in the same direction, $\mathrm{O}_{3}$ concentrations tend to change in the same corresponding direction, whereas temperature and insolation varying in opposite directions correspond with mixed changes in $\mathrm{O}_{3}$.

Decreases in daily mean precipitation are found over the Pacific coast, where some regions receive $2 \mathrm{~mm}$ less rain per day (or $30 \%$ less rain), on average, and some decreases were simulated over the southeastern region (Fig. 3a). Reduced rain along the Pacific coast occurs mostly during the winter, as a major portion of the western US sees greater than a $2 \mathrm{~mm}$ per day decrease. Correspondingly, insolation over the Pacific coast increases during the winter by up to $15 \mathrm{~W} \mathrm{~m}^{-2}$ (Fig. 4a). The Southeast experiences a similar magnitude of drying, but mainly during the fall. Both the 36 and the $12 \mathrm{~km}$ simulations over the Southeast predicted greater than $2 \mathrm{~mm}$ less rain per day during the fall (Figs. $3 \mathrm{c}$ and $4 \mathrm{c}$ ), which is also consistent with insolation changes in the region (increase of up to $10 \mathrm{~W} \mathrm{~m}^{-2}$ ). Interestingly, the high-resolution simulation predicts that the Southeast receives up to $2 \mathrm{~mm}$ per day more rain during the summer, which is not apparent in the $36 \mathrm{~km}$ domain. The 36 and $12 \mathrm{~km}$ resolution simulations over the Northeast, on the other hand, predict more rain over most of Vermont, New Hampshire and Maine during the 
a)

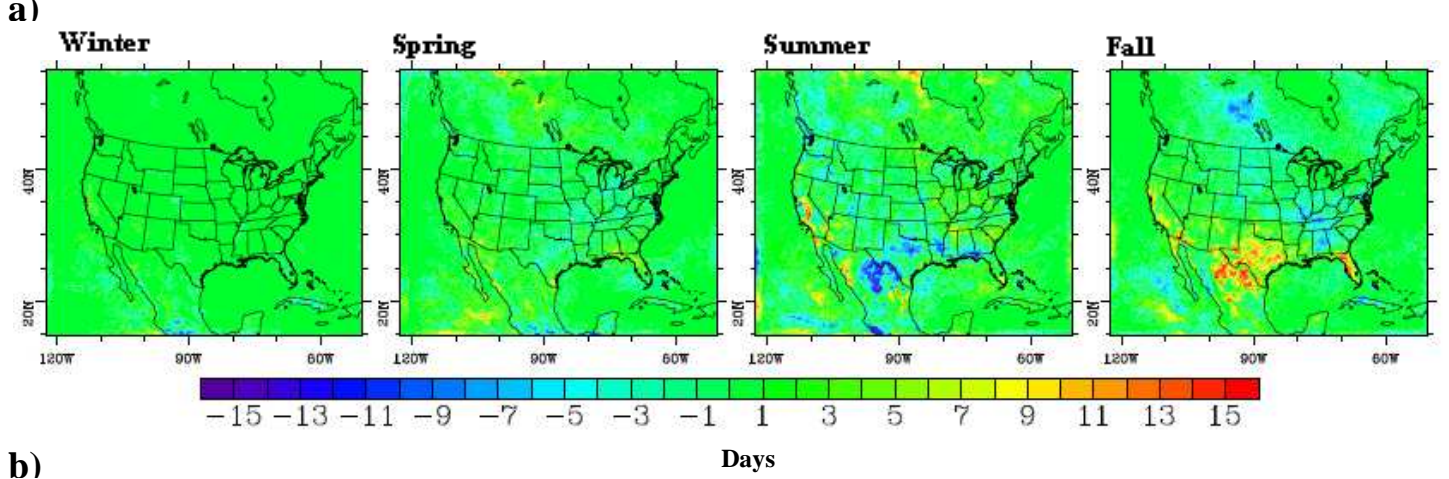

b)

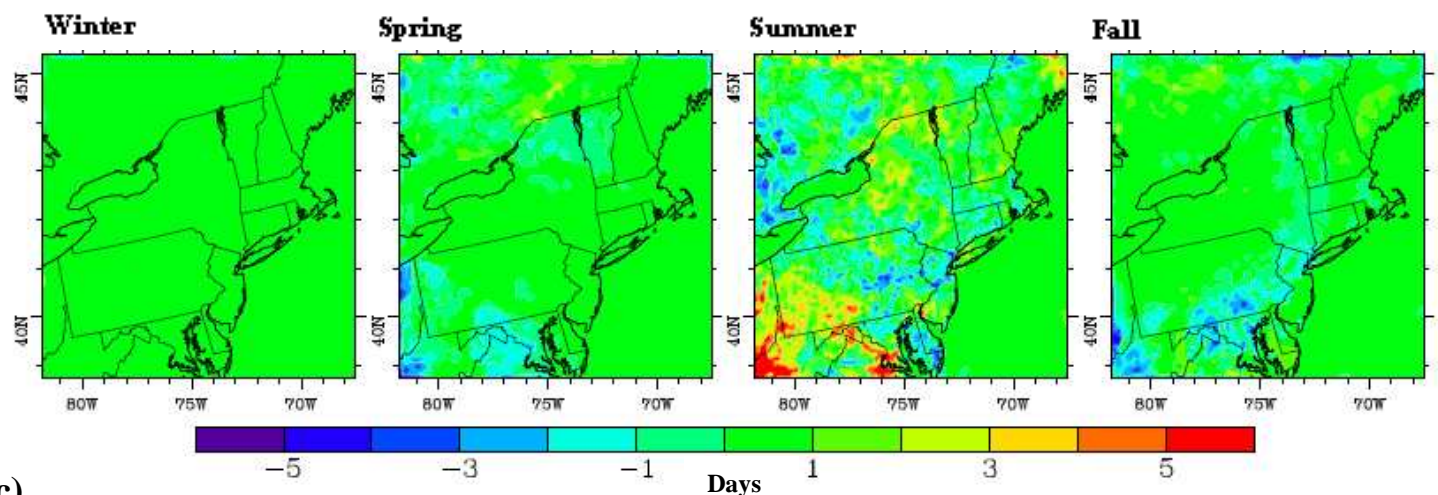

c)

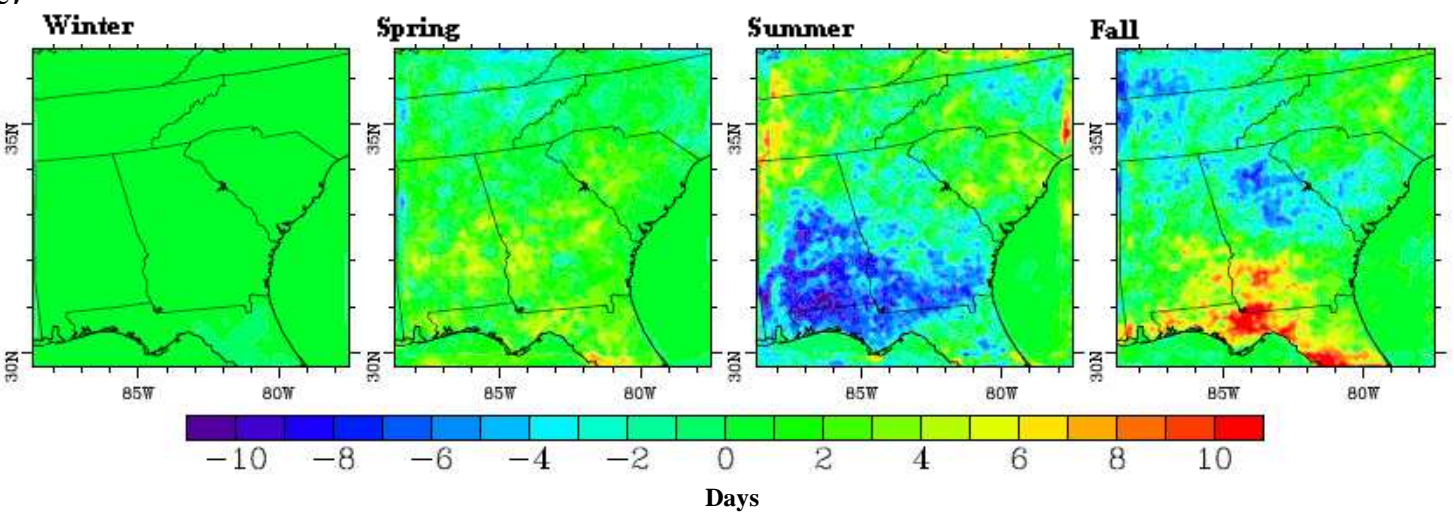

Fig. 5. Predicted total seasonal change in the number of stagnation days (days per season) (future minus historic) for (a) the $36 \mathrm{~km} \times 36 \mathrm{~km}$ resolution modeling domain, (b) the $12 \mathrm{~km} \times 12 \mathrm{~km}$ resolution sub-domain over the Northeast and (c) the $12 \mathrm{~km} \times 12 \mathrm{~km}$ resolution sub-domain over the Southeast.

summer, while most of Connecticut and New York receive less rain (Fig. 3b). The precipitation trend in the Northeast reverses during the fall, when Connecticut and New York receive more rain and the states farther north are dryer. There is a decrease in insolation of 5-15 $\mathrm{W} \mathrm{m}^{-2}$ during the spring and fall and an increase during the fall of $10-20 \mathrm{~W} \mathrm{~m}^{-2}$ over the Northeast (Fig. 4b). Correspondingly, the temperature only decreases slightly during spring, while it increases during summer. However, contrary to the insolation trend, the temperature in the Northeast sees large increases during fall.

\subsection{Stagnation events}

Stagnation events occur when wind speeds are low and little precipitation occurs over an extended period. A stagnation event is defined as at least four consecutive days when the following criteria are met: (a) the $10 \mathrm{~m}$ wind speed is less than $4 \mathrm{~m} \mathrm{~s}^{-1}$, (b) the $500 \mathrm{mb}$ wind speed is less than $13 \mathrm{~m} \mathrm{~s}^{-1}$ at 07:00 LST, and (c) the total rainfall is less than $0.001 \mathrm{~cm}$ for the 4-day period (Korshover and Angell, 1982). Since transport and deposition of pollutants are decreased during a stagnation period these events promote poor air quality. The number of stagnation days was compared to the National Centers for Environmental Prediction - North 
a)

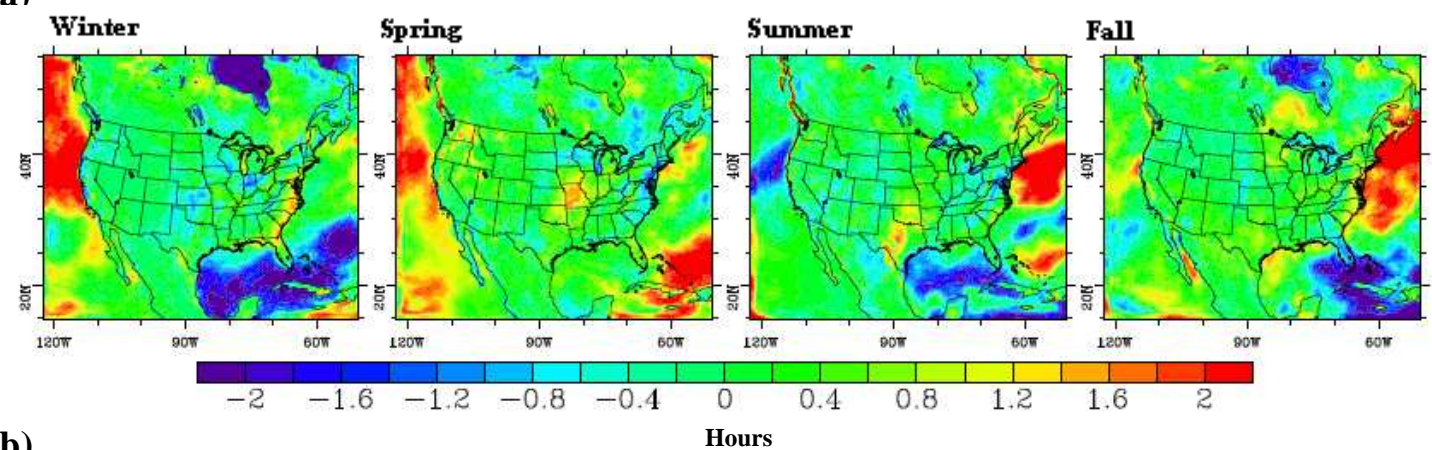

b)

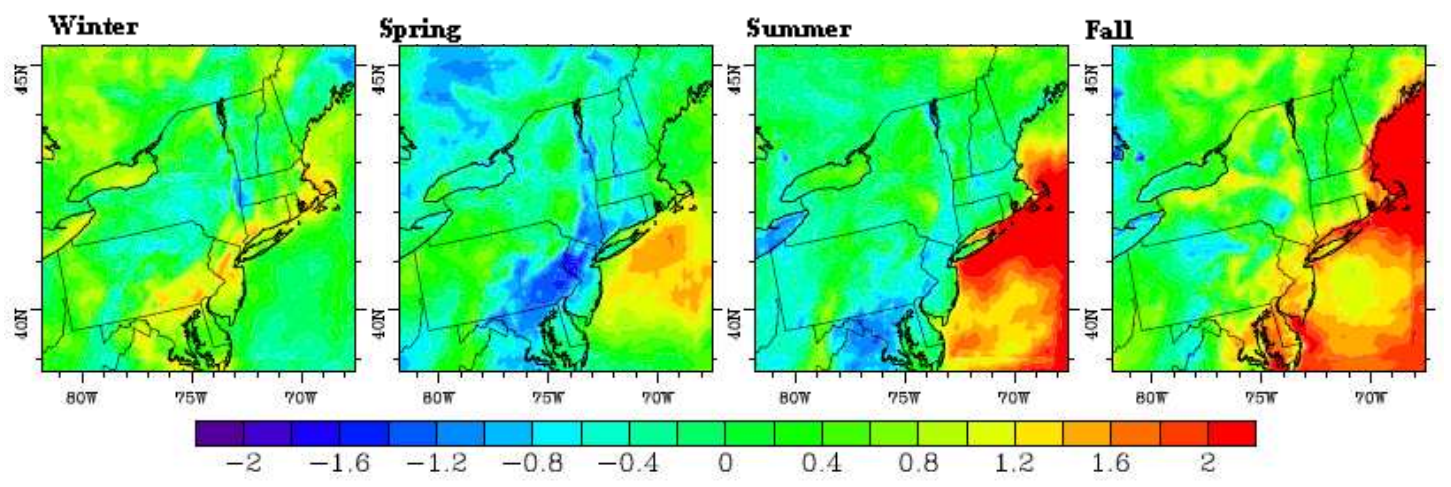

c)

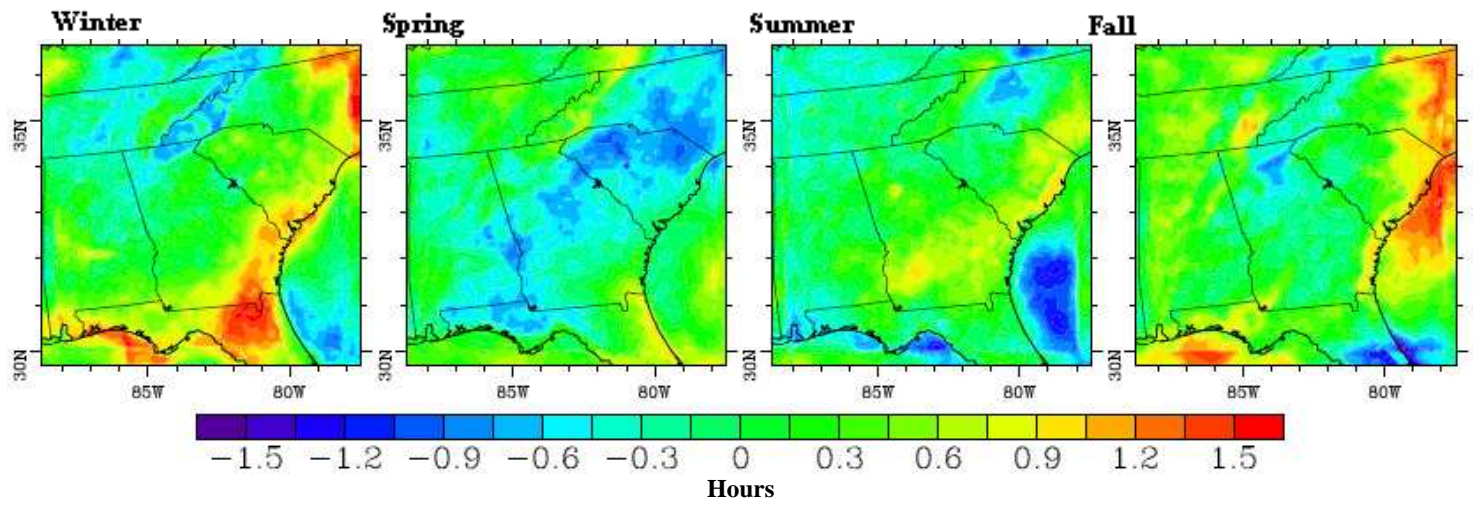

Fig. 6. Predicted total seasonal change in average unvented hours (hours per day) (future minus historic) for (a) the $36 \mathrm{~km} \times 36 \mathrm{~km}$ resolution modeling domain, (b) the $12 \mathrm{~km} \times 12 \mathrm{~km}$ resolution sub-domain over the Northeast and (c) the $12 \mathrm{~km} \times 12 \mathrm{~km}$ resolution sub-domain over the Southeast.

American Regional Reanalysis data (NCEP-NARR) for the year 2010. Results generally compare well, though with very similar regional spatial patterns. Low biases were found over Mexico and over the western US during the summer and fall. Stagnation is biased high in Texas during the summer (Fig. S2). During the winter and spring months, the spatial distribution of the number of stagnation days per season does not change significantly over the US (Fig. 5a). Over southern Texas, the number of stagnation days during fall increases in some small areas by 10 to 15 days per season, which correlates with the increase in temperature in the region. Large portions of this region already see over 30 days of stagnation per season. Stagnation decreases over Texas during the summer. Over most of the Southeast stagnation days also decrease by up to 10 days per season, corresponding to the increase in precipitation (Fig. 5c), which is large compared to the average number of stagnation days during the summer of the historic simulation (between 15 and 30). While the $36 \mathrm{~km}$ domain shows little change in stagnation in the Northeast, the high-resolution simulation shows stagnation increases of up to 5 days per season during the summer over parts of the Northeast, which is large compared to the average 5 to 10 stagnation days per season that occur in this region (Fig. 5b). Increased summertime stagnation in the $12 \mathrm{~km}$ 

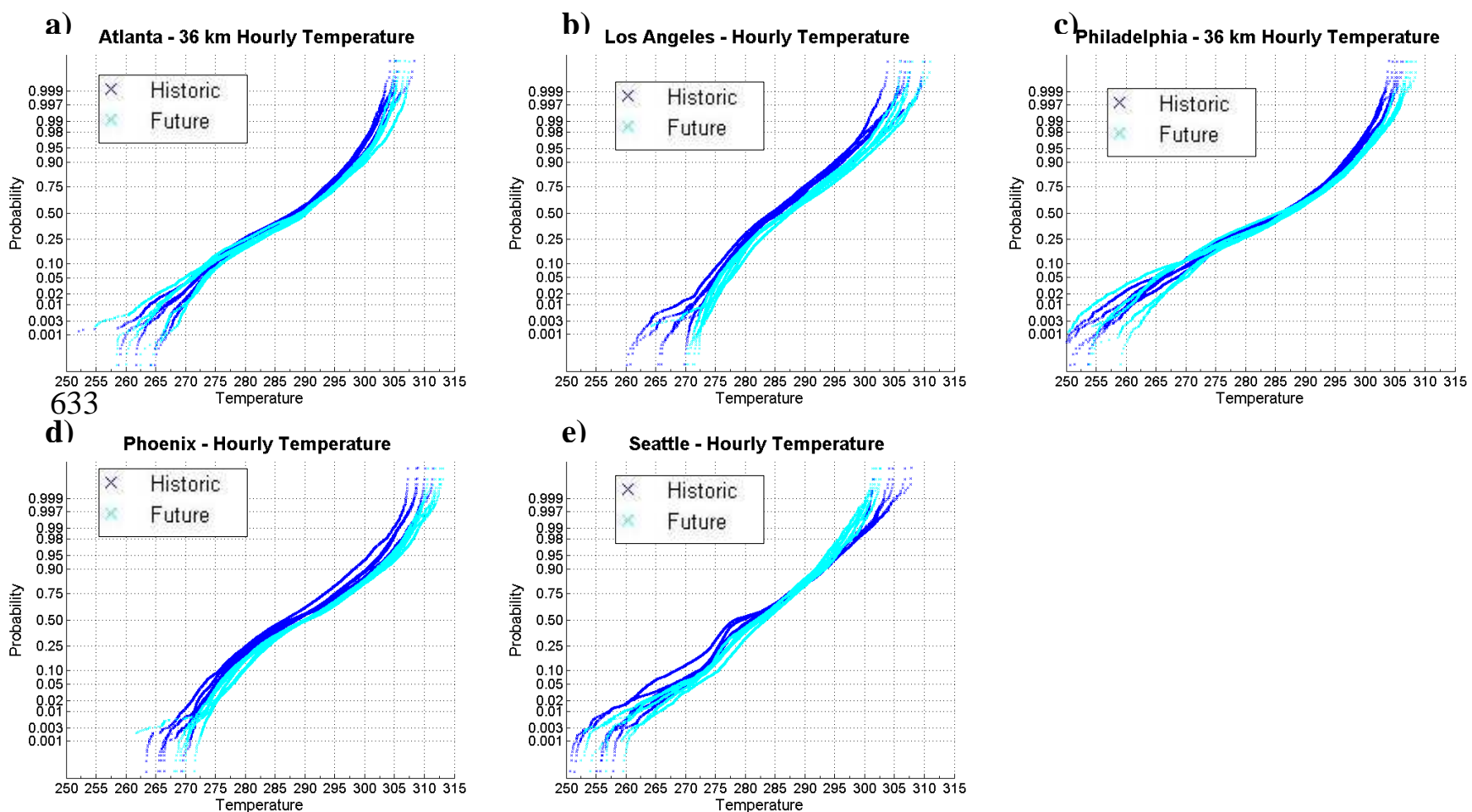

Fig. 7. Empirically determined cumulative distribution of $36 \mathrm{~km}$ historic (2006-2010) and future (2048-2050) hourly temperatures at major US cities: (a) Atlanta (b) Los Angeles (c) Philadelphia (d) Phoenix and (e) Seattle.

Northeast domain corresponds to precipitation decreases in the same domain. During fall, a large increase (over 15 days) in the number of stagnation days is found along the Gulf coast and the California coast. Along the coast of California during fall, the increase in stagnation days leads to increased concentrations of pollutants, reinforcing the negative impact that increased temperature and insolation have on air quality in the area. Similarly, the decreased precipitation along the Gulf coast may reinforce higher concentrations of pollutants due to increased stagnation in the area.

\subsection{Ventilation}

The ventilation coefficient, which is defined as the product of the mean wind speed within the boundary layer and the boundary layer height (Pielke et al., 1991), reflects how well pollutants can be mixed and transported within the boundary layer. Ventilation is adversely impacted by stagnation, which is driven by the persistence of certain large-scale circulation patters, but also takes into account smaller-scale meteorological conditions. An unvented hour is an hour during which the ventilation coefficient is less than $6000 \mathrm{~m}^{2} \mathrm{~s}^{-1}$ (Pielke et al., 1991). Seasonal mean ventilation coefficients were compared with NCEP-NARR data, and similar spatial and seasonal patterns were found. There was a low bias in the western US while the Northeast and the Southeast compare well with reanalysis data (Fig. S3). During summer, Texas has on average 1 to 2 more unvented hours per day in the future compared to the present, which tends to increase pollutant concentrations, further amplifying the increased concentrations of $\mathrm{O}_{3}$ and some secondary PM (with the exception of volatile PM such as ammonium nitrate) due to increased temperatures in the region (Fig. 6a). The $12 \mathrm{~km} \mathrm{sim-}$ ulation shows that the coast of Georgia and the Carolinas also see 1 to 2 more unvented hours per day during the summer, while the $36 \mathrm{~km}$ simulation shows less dramatic changes over the Southeast. Summertime differences between the two domains occur, in part, due to differences in the resolutions of the land use data since southeastern Georgia and South Carolina are scattered with pine forest and cropland and these two land use categories affect surface energy fluxes and PBL height differently, which in turn affects the ventilation in the region. During fall, an increase of 1 to 2 unvented hours per day is found over much of the Northeast and Southeast. The higher-resolution domains show similar trends, although with more spatial variability. In the Northeast, the combination of higher temperatures and less ventilation would lead to higher concentration of pollutants, while the decrease in insolation would reduce secondary pollutants such as $\mathrm{O}_{3}$ and secondary PM (Fig. 6b). Unvented hours over most of Minnesota increase during spring by over $3 \mathrm{~h}$ per day; however, none of the other variables examined here show either a reinforcing or competing effect on air quality. 

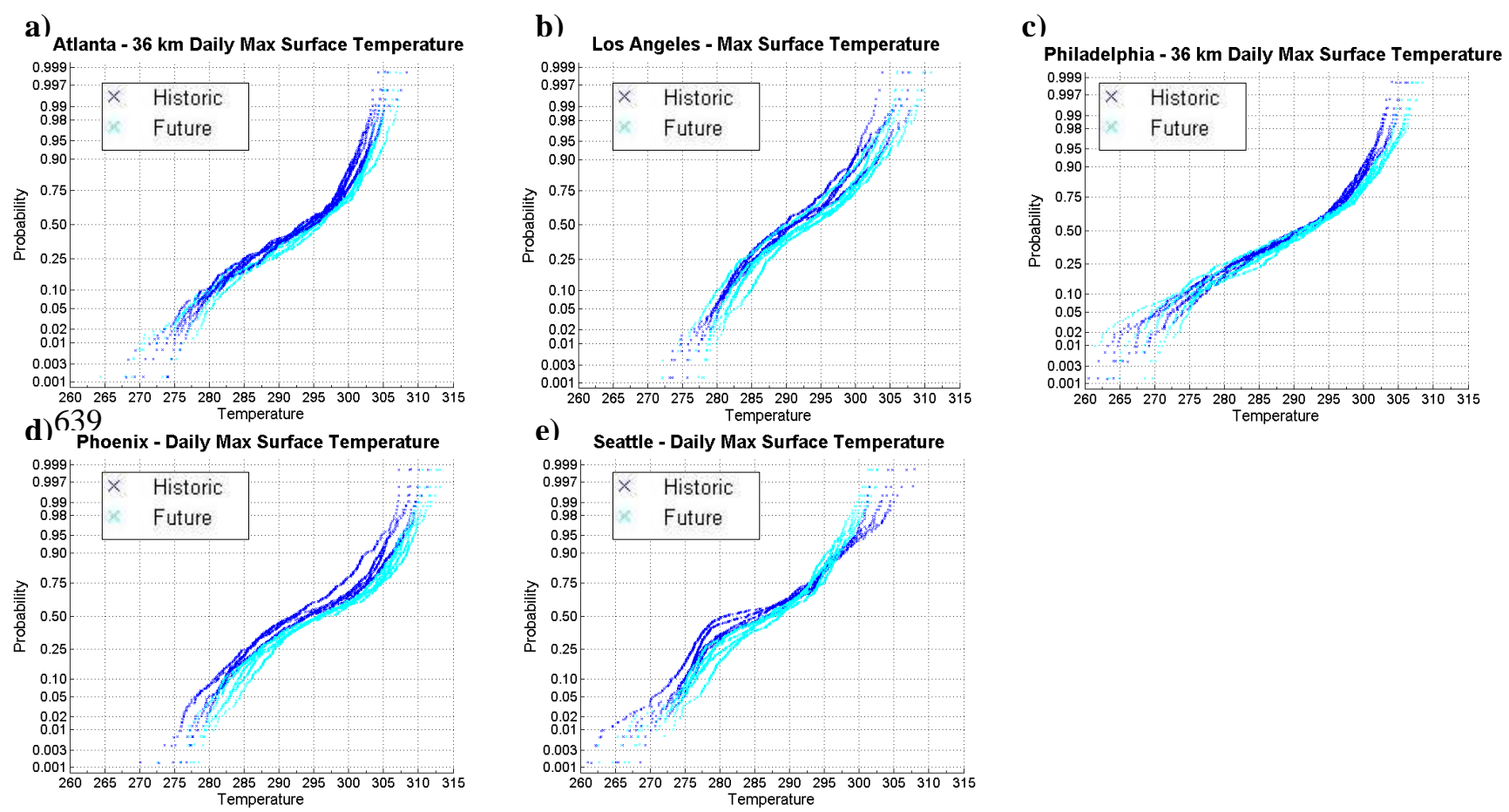

Fig. 8. Empirically determined cumulative distribution of $36 \mathrm{~km}$ historic (2006-2010) and future (2048-2050) maximum daily $1 \mathrm{~h}$ average temperature at major US cities: (a) Atlanta (b) Los Angeles (c) Philadelphia (d) Phoenix and (e) Seattle.

\subsection{Regional climate and urban centers}

Since a large and growing fraction of the nation's population is located in dense urban areas, it is important to examine the change in air-quality-related climate variables over some major US cities. The expected response to climate change differs among various different regions of the US. Here we focus on 5 geographically unique, densely populated cities that are representative of the different regions of the US: Atlanta, Los Angeles, Philadelphia, Phoenix, and Seattle. Further, land use changes may exacerbate meteorological changes in cities. Philadelphia and Phoenix are chosen here, rather than more populous cities such as New York and Houston, because future studies are planned to address the impact of land use changes on regional climate in those cities. Extremes in meteorological variables are important because there are adverse health effects associated with short term exposure to poor air quality. Air pollution is highly variable in time, and temperature extremes are also associated with adverse health outcomes (McMichael et al., 2006). Cumulative distribution function (CDF) plots show the percentage of hourly temperature and daily precipitation that exceed a given value in major US cities for each simulation year (Fig. 7a-e). The hourly temperatures within any given percentile range tend to shift a few degrees warmer in the future, except for the lower 20th percentile range in Atlanta and Philadelphia and the upper 90th percentile range in Seattle,. Most warming in Seattle occurs at the lower 75th percentile range, where high $\mathrm{O}_{3}$ concentrations are not likely, which reflects the increase in temperature mentioned earlier during the winter in the Pacific Northwest. This can also decrease emissions related to domestic heating, including PM from wood burning. The cumulative distribution of the maximum daily temperature in Seattle follows a similar trend, as the hourly CDF in the lower range and temperature are nearly the same in the 60th to 90th percentile range (Fig. 8a-e). The upper 95th percentile in daily maximum temperatures in Seattle are actually around a degree cooler in the future, decreasing the chance of high ozone during hot days (Table 3). Los Angeles and Phoenix have similar hourly temperature and maximum temperature CDF structures and shifts from present to future. These cities are warmed by 1 to 3 degrees regardless of the percentile range. Lin et al. (2001) have developed estimates of the probability that the maximum daily $8 \mathrm{~h}$ average $\mathrm{O}_{3}$ will exceed $80 \mathrm{ppb}$ given the maximum daily temperature in a given region (including Los Angeles, the Southeast, and the Northeast). Given that the upper 95 th percentile in daily maximum temperatures in Phoenix increases from around $306 \mathrm{~K}$ to $309 \mathrm{~K}$, the probability that $\mathrm{O}_{3}$ will exceed $80 \mathrm{ppb}$ on these days increases. Similarly, a shift in the upper 95th percentile in daily maximum temperatures in Los Angeles, from around $302 \mathrm{~K}$ to $305 \mathrm{~K}$, also increases the probability of high $\mathrm{O}_{3}$. The coolest days in Atlanta and Philadelphia are similar to, if not cooler than, the future simulations, reflecting the cooling that occurs during the winter and spring in the surrounding 
a)

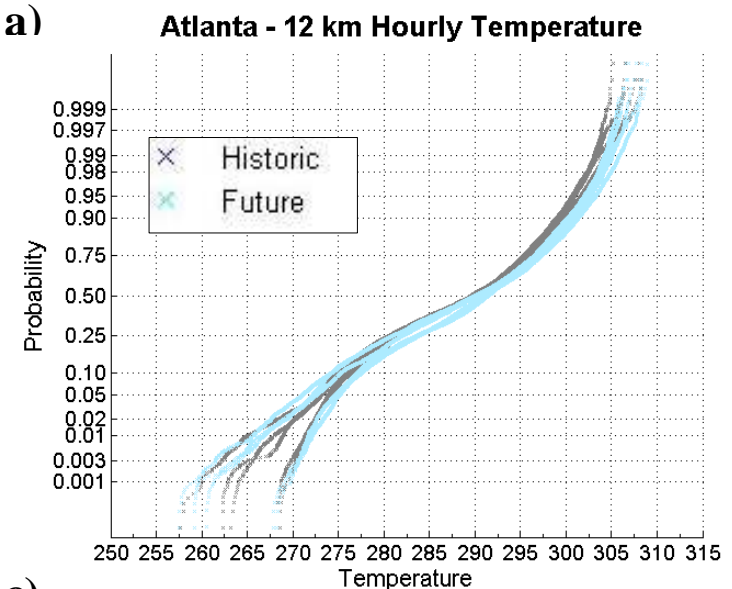

c)

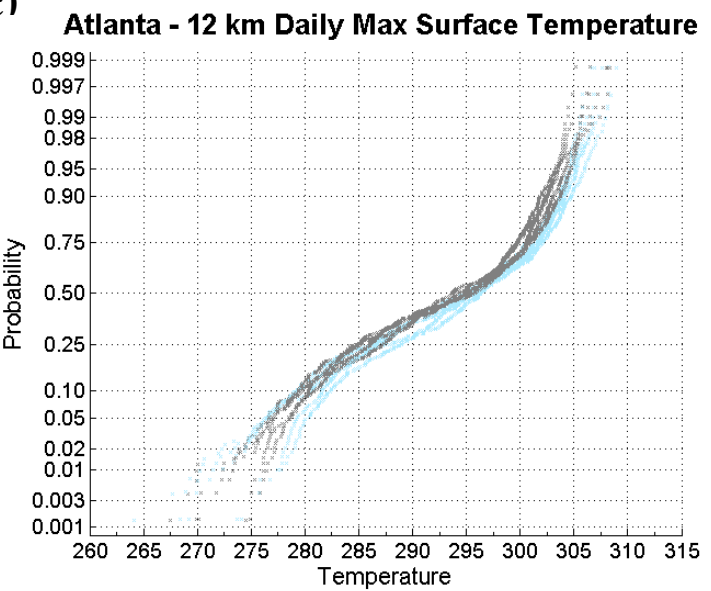

b)

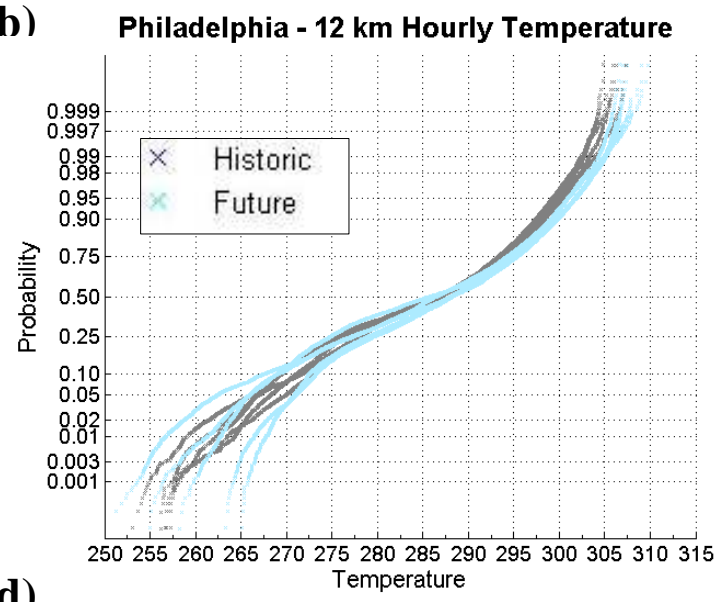

d)

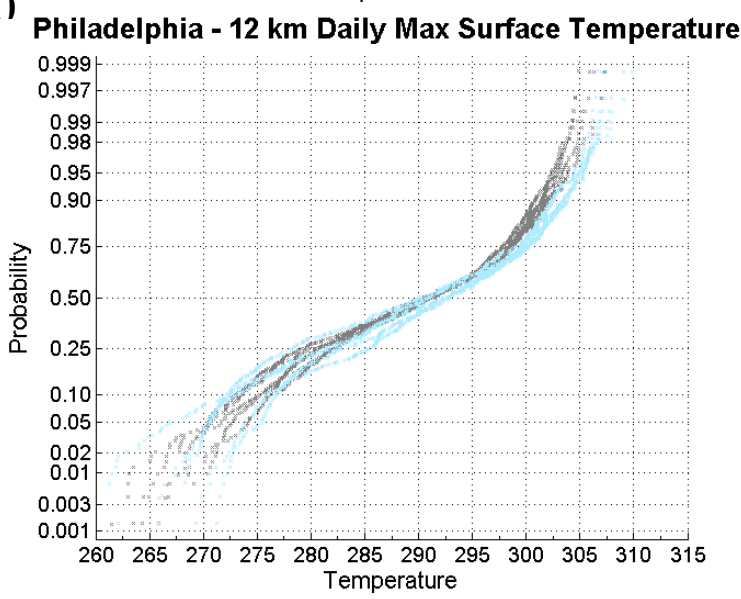

Fig. 9. Empirically determined cumulative distribution of $12 \mathrm{~km}$ historic (2006-2010) and future (2048-2050) hourly temperature at (a) Atlanta and (b) Philadelphia, and maximum daily $1 \mathrm{~h}$ average temperature at (c) Atlanta and (d) Philadelphia.

regions. While very little, if any, warming occurs in the lower 50th percentile of daily maximum temperature, the upper 95th percentile maximum temperatures in Philadelphia and Atlanta increase from around $301 \mathrm{~K}$ to $304 \mathrm{~K}$ and $302 \mathrm{~K}$ to about $304 \mathrm{~K}$, respectively, with a corresponding increase in probability of high $\mathrm{O}_{3}$ concentrations on those hot days. The $12 \mathrm{~km}$ simulations produce similar, but not identical, cumulative distribution of total hourly temperatures and maximum temperatures in Atlanta and Philadelphia (Fig. 9). The $12 \mathrm{~km}$ domains show a shift in daily maximum temperature at the upper 95th percentile of 303 to $305 \mathrm{~K}$ in both Philadelphia and Atlanta, implying a higher probability of high ozone on those days than would be derived from the coarse resolution. The hottest days in Philadelphia are simulated by the future $12 \mathrm{~km}$ domain, where temperatures reach $310 \mathrm{~K}$. Maximum temperatures and high $\mathrm{O}_{3}$ probability in New York exhibit similar changes to that of Philadelphia. Temperature distributions in Chicago were also analyzed; however the only difference from present to future is a shift in the upper 95th percentile from 300 to $301 \mathrm{~K}$, while the distribution below the 90th percentile does not change.
Rain can improve air quality, and although the seasonal mean precipitation has already been examined, it is important to also understand how the frequency and distribution of rainfall can shift over time. Rainfall frequency shifts are especially important in cities, where frequent light rains will clean the air more than infrequent heavy rains. The most notable change in daily precipitation distribution occurs in Los Angeles, where the driest year is simulated in the future and the wettest year is simulated in the historic simulations (Fig. 10). Seattle does not seem to receive more or less rain in the future but does have a more consistent distribution of daily rainfall from year to year in the future. The precipitation distributions of the remaining cities do not appear to be affected. Precipitation distributions produced from the $12 \mathrm{~km}$ simulations over Atlanta and Philadelphia are similar to the distribution produced by the coarse simulation (Fig. S4). 
a)
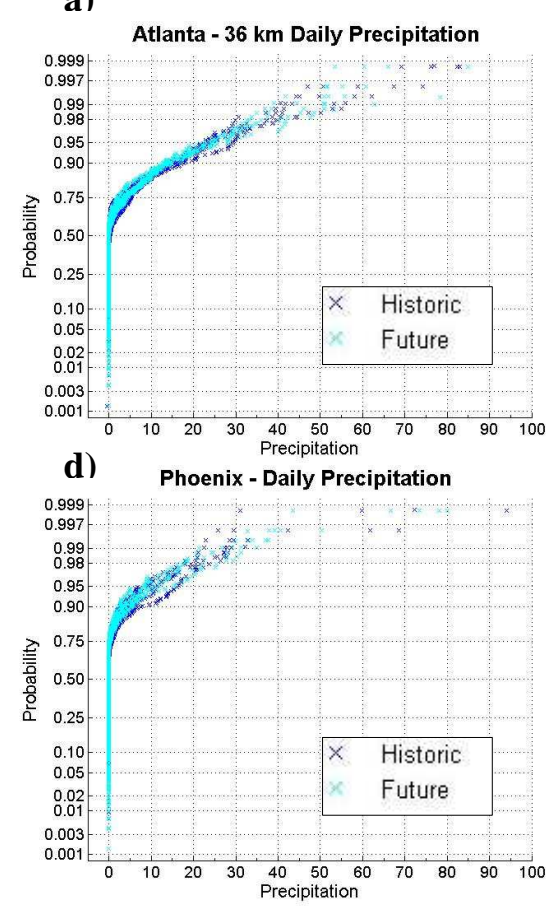

b)
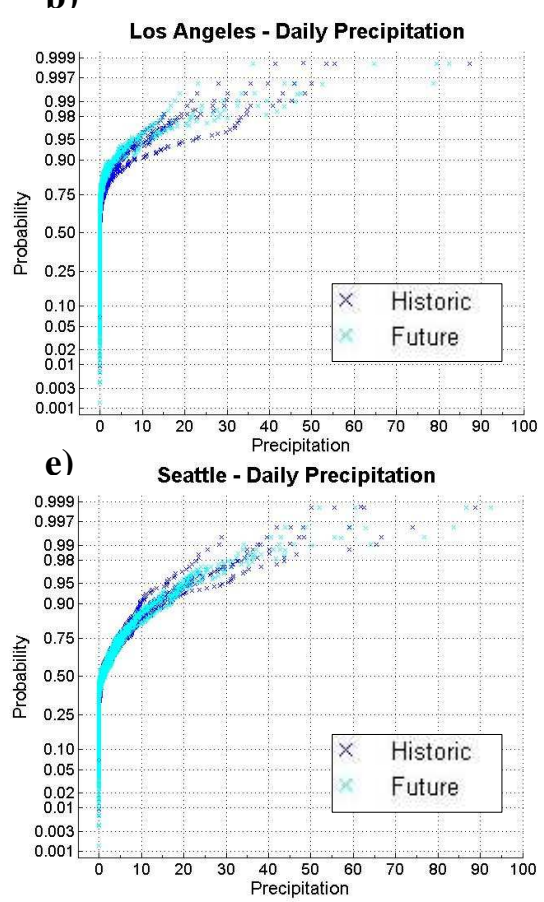

c)

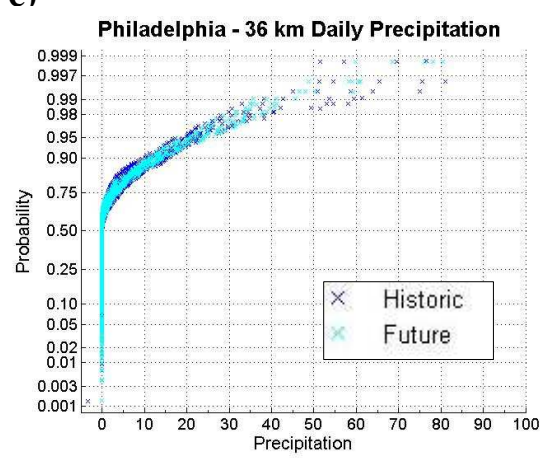

Fig. 10. Cumulative distribution of $36 \mathrm{~km}$ historic (dark) and future (light) daily precipitation at major US cities: (a) Atlanta (b) Los Angeles (c) Philadelphia (d) Phoenix and (e) Seattle.

\section{Conclusions}

The high-resolution simulations produce somewhat different results than the coarse-resolution simulations in some regions. Also, through the analysis of the meteorological variables that most strongly influence air quality, we find consistent changes in regional climate that would enhance ozone levels in four regions of the US during fall (western US, Texas, northeastern, and southeastern US), one region during summer (Texas), and one region where changes potentially would lead to better air quality during spring (Northeast).

During summer and fall, all air quality indicators, with the exception of insolation and precipitation, suggest an increase in air pollutant concentrations, including increased production of secondary $\mathrm{PM}$ and $\mathrm{O}_{3}$, in most of Texas. Consistent with Leung and Gustafson (2005), when comparing 20482052 to 2006-2010, we find warmer temperatures (2-3 K), less ventilation (1-2h per day) and more stagnation (1015 days per season) during summer in Texas and the same for fall, though slightly less intense.

The west coast is marked by warmer temperatures (ranging from $1-4 \mathrm{~K}$ ), slightly less rainfall (less than $1 \mathrm{~mm}$ per day), and more stagnation (10-15 days) during fall, while there is no significant change in ventilation and insolation. Similarly during fall, the Southeast shows little change in ventilation and stagnation but is warmer (2-3 K), dryer (up to $2 \mathrm{~mm}$ per day in some areas) and with slightly higher insolation $\left(5-10 \mathrm{~W} \mathrm{~m}^{-2}\right)$. Also, the shift in the distribution of maximum daily temperatures in Atlanta increases the probability of high $\mathrm{O}_{3}$ concentrations for days when the maximum temperature is in the 95th percentile.

The Northeast is also warmer during fall $(2-3 \mathrm{~K})$ and less ventilated (1-2h per day), but increased rainfall (up to $2 \mathrm{~mm}$ per day) and decreased insolation $\left(\sim 5 \mathrm{~W} \mathrm{~m}^{-2}\right)$ compete for better air quality. Regardless, as in Atlanta, the shift in the distribution of maximum daily temperature in New York and Philadelphia increases the probability of high $\mathrm{O}_{3}$ concentrations $(0.06-0.12)$ for days when the maximum temperature is in the 95th percentile. During spring, however, increased rain (1-2 mm per day), more ventilation ( $\sim \mathrm{h}$ per day) and decreased temperatures $(\sim 1 \mathrm{~K})$ could promote better air quality in the Northeast.

While climate conditions strongly impact air quality, emissions and chemistry also play a vital and complex role in the formation and removal of atmospheric pollutants. A more comprehensive assessment of emissions and chemistry will be addressed in the future.

Supplementary material related to this article is available online at: http://www.geosci-model-dev.net/6/ 1429/2013/gmd-6-1429-2013-supplement.pdf. 
Acknowledgements. While this work was supported, in part, by grants from the US EPA (EPA-G2008-STAR-J1) and NASA, reference herein to any specific commercial products, process, or service by trade name, trademark, manufacturer, or otherwise, does not necessarily constitute or imply their endorsement or recommendation. The views and opinions of authors expressed herein are those of the authors and do not necessarily state or reflect those of the United States Government.

Edited by: R. Sander

\section{References}

Byun, D. and Schere, K.: Review of the Governing Equations, Computational Algorithms, and Other Components of the Models-3 Community Multiscale Air Quality (CMAQ) Modeling System, Appl. Mech. Rev., 59, 51-77, 2006.

Dawson, J. P., Racherla, P. N., Lynn, B. H., Adams, P. J., and Pandis, S. N.: Simulating present-day and future air quality as climate changes: Model evaluation, Atmos. Environ., 42, 45514566, doi:10.1016/j.atmosenv.2008.01.058, 2008.

Dudhia, J.: Numerical study of convection observed during the winter monsoon experiment using a mesoscale two-dimensional model, J. Atmos. Sci., 46, 3077-3107, 1989.

Ek, M. B., Mitchell, K. E., Lin, Y., Rogers, E., Grunmann, P., Koren, V., Gayno, G., and Tarpley, J. D.: Implementation of Noah land surface model advances in the National Centers for Environmental Prediction operational mesoscale Eta model, J. Geophys. Res.-Atmos., 108, 8851, doi:10.1029/2002jd003296, 2003.

Emery, C. and Tai, E.: Meteorological Modeling and Performance Evaluation of the September 13-20, 1999 Ozone Episode, prepared for the Texas Near Non-Attainment Areas through the Alamo Area Council of Governments, by ENVIRON International Corp, Navato, CA, 2001.

EPA, U. S.: The potential effects of global climate change on the United States, EPA, EPA-230-05-89-050, p. 457, 1989.

Giorgi, F.: Regional climate modeling: Status and perspectives, J. Phys. IV, 139, 101-118, doi:10.1051/jp4:2006139008, 2006.

Grell, G. A., Dudhia, J., and Stauffer, D. R. A: A description of the fifth generation Penn State/NCAR mesoscale model (MM5), National Center for Atmospheric Research, Boulder, CO, 1994.

Hong, S. Y., Noh, Y., and Dudhia, J.: A new vertical diffusion package with an explicit treatment of entrainment processes, Mon. Weather Rev., 134, 2318-2341, 2006.

IMAGE_Team: The IMAGE 2.2 implementation of the SRES scenarios. A comprehensive analysis of emissions, climate change and impacts in the 21st century, National Institute for Public Health and the Environment, Bilthoven, the Netherlands., RIVM publication 481508019, 2001.

Jacob, D. J. and Winner, D. A.: Effect of climate change on air quality, Atmos. Environ., 43, 51-63, doi:10.1016/j.atmosenv.2008.09.051, 2009.

Kain, J. S. and Fritsch, J. M.: Convective parameterization models: The Kain-Fritsch scheme, Cumulus Convection in Numerical Models, Am. Meteorol. Soc., 46, 165-170, 1993.

Korshover, J. and Angell, J. K.: A review of air-stagnation cases in the Eastern-United-States during 1981 - Annual summary, Mon. Weather Rev., 110, 1515-1518, doi:10.1175/15200493(1982) $110<1515$ :aroasc $>2.0$. co;2, 1982.
Lamarque, J. F., Kyle, G. P., Meinshausen, M., Riahi, K., Smith, S. J., van Vuuren, D. P., Conley, A. J., and Vitt, F.: Global and regional evolution of short-lived radiatively-active gases and aerosols in the Representative Concentration Pathways, Climatic Change, 109, 191-212, doi:10.1007/s10584-011-0155-0, 2011.

Leung, L. R. and Gustafson, W. I.: Potential regional climate change and implications to US air quality, Geophys. Res. Lett., 32, L16711 doi:10.1029/2005g1022911, 2005.

Liao, H., Chen, W. T., and Seinfeld, J. H.: Role of climate change in global predictions of future tropospheric ozone and aerosols, J. Geophys. Res.-Atmos., 111, D12304, doi:10.1029/2005jd006852, 2006.

Liao, K. J.,Tagaris, E., Manomaiphiboon, K., Napelenok, S. L., Woo, J. H., He, S., Amar, P., and Russell, A. G.: Sensitivities of ozone and fine particulate matter formation to emissions under the impact of potential future climate change, Environ. Sci. Technol., 41, 8355-8361, 2007.

Lin, Y. L., Farley, R. D., and Orville, H. D.: Bulk parameterization of the snow field in a cloud model, J. Climate Appl. Meteorol., 22, 1065-1092, doi:10.1175/15200450(1983)022<1065:bpotsf >2.0.co;2, 1983.

Liu, P., Tsimpidi, A. P., Hu, Y., Stone, B., Russell, A. G., and Nenes, A.: Differences between downscaling with spectral and grid nudging using WRF, Atmos. Chem. Phys., 12, 3601-3610, doi:10.5194/acp-12-3601-2012, 2012.

McMichael, A. J., Woodruff, R. E., and Hales, S.: Climate change and human health: present and future risks, Lancet, 367, 859869, doi:10.1016/s0140-6736(06)68079-3, 2006.

Mickley, L. J., Jacob, D. J., Field, B. D., and Rind, D.: Effects of future climate change on regional air pollution episodes in the United States, Geophys. Res. Let., 31, L24103, doi:10.1029/2004g1021216, 2004.

Mlawer, E. J., Taubman, S. J., Brown, P. D., Iacono, M. J., and Clough, S. A.: Radiative transfer for inhomogeneous atmospheres: RRTM, a validated correlated-k model for the longwave, J. Geophys. Res.-Atmos., 102, 16663-16682, doi:10.1029/97jd00237, 1997.

Moss, R. H., Edmonds, J. A., Hibbard, K. A., Manning, M. R., Rose, S. K., van Vuuren, D. P., Carter, T. R., Emori, S., Kainuma, M., Kram, T., Meehl, G. A., Mitchell, J. F. B., Nakicenovic, N., Riahi, K., Smith, S. J., Stouffer, R. J., Thomson, A. M., Weyant, J. P., and Wilbanks, T. J.: The next generation of scenarios for climate change research and assessment, Nature, 463, 747-756, doi:10.1038/nature08823, 2010.

Nolte, C. G., Gilliland, A. B., Hogrefe, C., and Mickley, L. J.: Linking global to regional models to assess future climate impacts on surface ozone levels in the United States, J. Geophys. Res.Atmos., 113, D14307, doi:10.1029/2007JD008497, 2008.

Pielke, R. A., Stocker, R. A., Arritt, R. W., and McNider, R. T.: A procedure to estimate worst-case air-quality in complex terrain, Environ. Int., 17, 559-574, doi:10.1016/0160-4120(91)90168-p, 1991.

Rind, D. and Lerner, J.: Use of on-line tracers as a diagnostic tool in general circulation model development .1. Horizontal and vertical transport in the troposphere, J. Geophys. Res.-Atmos., 101, 12667-12683, doi:10.1029/96jd00551, 1996.

Rind, D., Lerner, J., Shah, K., and Suozzo, R.: Use of on-line tracers as a diagnostic tool in general circulation model development 2. Transport between the troposphere and stratosphere, J. Geo- 
phys. Res.-Atmos., 104, 9151-9167, doi:10.1029/1999jd900006, 1999.

Skamarock, W. C. and Klemp, J. B.: A time-split nonhydrostatic atmospheric model for weather research and forecasting applications, J. Comput. Phys., 227, 3465-3485, doi:10.1016/j.jcp.2007.01.037, 2008.

Stauffer, D. R. and Seaman, N. L.: Use of a 4-dimensional data assimilation in a limeted-area mesoscale model .1. Experiments with synoptic-scale data, Mon. Weather Rev., 118, 1250-1277, doi:10.1175/1520-0493(1990)118<1250:uofdda > 2.0.co;2, 1990.

Stevenson, D. S., Dentener, F. J., Schultz, M. G., Ellingsen, K., van Noije, T. P. C., Wild, O., Zeng, G., Amann, M., Atherton, C. S., Bell, N., Bergmann, D. J., Bey, I., Butler, T., Cofala, J., Collins, W. J., Derwent, R. G., Doherty, R. M., Drevet, J., Eskes, H. J., Fiore, A. M., Gauss, M., Hauglustaine, D. A., Horowitz, L. W., Isaksen, I. S. A., Krol, M. C., Lamarque, J. F., Lawrence, M. G., Montanaro, V., Muller, J. F., Pitari, G., Prather, M. J., Pyle, J. A., Rast, S., Rodriguez, J. M., Sanderson, M. G., Savage, N. H., Shindell, D. T., Strahan, S. E., Sudo, K., and Szopa, S.: Multimodel ensemble simulations of present-day and near-future tropospheric ozone, J. Geophys. Res.-Atmos., 111, D08301, doi:10.1029/2005JD006338, 2006.

Tagaris, E., Manomaiphiboon, K., Liao, K. J., Leung, L. R., Woo, J. H., He, S., Amar, P., and Russell, A. G.: Impacts of global climate change and emissions on regional ozone and fine particulate matter concentrations over the United States, J. Geophys. Res.-Atmos., 112, D14312, doi:10.1029/2006JD008262, 2007.
Weaver, C. P., Liang, X. Z., Zhu, J., Adams, P. J., Amar, P., Avise, J., Caughey, M., Chen, J., Cohen, R. C., Cooter, E., Dawson, J. P., Gilliam, R., Gilliland, A., Goldstein, A. H., Grambsch, A., Grano, D., Guenther, A., Gustafson, W. I., Harley, R. A., He, S., Hemming, B., Hogrefe, C., Huang, H. C., Hunt, S. W., Jacob, D. J., Kinney, P. L., Kunkel, K., Lamarque, J. F., Lamb, B., Larkin, N. K., Leung, L. R., Liao, K. J., Lin, J. T., Lynn, B. H., Manomaiphiboon, K., Mass, C., McKenzie, D., Mickley, L. J., O’Neill, S. M., Nolte, C., Pandis, S. N., Racherla, P. N., Rosenzweig, C., Russell, A. G., Salathe, E., Steiner, A. L., Tagaris, E., Tao, Z., Tonse, S., Wiedinmyer, C., Williams, A., Winner, D. A., Woo, J. H., Wu, S., and Wuebbles, D. J.: A preliminary synthesis of modeled climate change impacts on US regional ozone concentrations, B. Am. Meteorol. Soc., 90, 1843-1863, doi:10.1175/2009bams2568.1, 2009.

Woo, J. H., He, S., Tagaris, E., Liao, K. J., Manomaiphiboon, K., Amar, P. , and Russell, A. G.: Development of North American Emission Inventories for Air Quality Modeling under Climate Change, J. Air Waste Manage. Assoc., 58, 1483-1494, doi:10.3155/1047-3289.58.11.1483, 2008.

Yu, S. C., Eder, B., Dennis, R., Chu, S. H., and Schwartz, S. E.: New unbiased symmetric metrics for evaluation of air quality models, Atmos. Sci. Lett., 7, 26-34, doi:10.1002/asl.125, 2006. 